\title{
Visual Evaluation of Soil Structure in Maize and Forage Grasses Intercropping under No-Tillage
}

\author{
Maria Caroline Garcia Paschoal ${ }^{1 *}$ \\ https://orcid.org/0000-0001-9668-8345 \\ Camila Pereira Cagna ${ }^{1}$ \\ https://orcid.org/0000-0002-1113-013X \\ Osvaldo Guedes Filho' \\ https://orcid.org/0000-0001-8550-8505 \\ Renata Bachin Mazzini-Guedes 1 \\ https://orcid.org/0000-0003-2424-4862 \\ ${ }^{1}$ Federal University of Paraná State, Advanced Campus of Jandaia do Sul, Jandaia do Sul, Paraná, Brazil. \\ Received: 2019.08.15; Accepted: 2020.03.09. \\ *Correspondence: maria_carolineg@hotmail.com; Tel.: +55-43-996342479 (M. C. G. P.)
}

\section{HIGHLIGHTS}

- Maize and forage grasses intercropping improves soil structural quality.

- Visual evaluation was used to access the soil structural quality.

- Non-intercropping maize received the worst visual score.

- Maize with Urochloa brizantha cv. Xaraés presented an excellent visual score.

Abstract: The objective was to undertake the visual evaluation of soil structure in maize and forage grasses intercropping under no-tillage. The experiment was carried out in a rural property located in North Paraná State, Brazil, where there were five parallel areas with the following treatments: maize + Urochloa brizantha cv. Marandu (T1), maize + Urochloa brizantha cv. Piatã (T2), maize + Urochloa brizantha cv. Xaraés (T3), maize + Urochloa ruziziensis (T4), and non-intercropping maize (T5). Seeds of forage grasses were sown in April $5^{\text {th }}, 2018$ and sampling was carried out in December, $30^{\text {th }}, 2018$. Samples of $0.10 \mathrm{~m}$ width, $0.20 \mathrm{~m}$ length, and $0.25 \mathrm{~m}$ thickness were collected from five random locations of each experimental area and, for the visual evaluation of soil structural quality, a soil evaluation (VESS) chart was used so that visual scores were attributed to each sample. Treatments 1 and 5 received the highest scores, while treatment 3 had the lowest score and showed good structural quality and great root presence. At the superficial layer, treatment 2 had the lowest score (0.8) among treatments. For the subsuperficial layer, the scores obtained were higher than those found for the superficial layer: T3 had the lowest mean (1.5) and was significantly similar to T4 that presented a mean score of 1.7. Except for T1, which showed a similar score to non-intercropping maize (T5), the forage grasses had better visual scores. The visual evaluation of soil structure indicated that maize and forage grasses intercropping improves soil structural quality.

Keywords: soil structural quality; soil management; visual score; VESS. 


\section{INTRODUCTION}

Soil management is one of the greatest challenges endured by farmers as its intensive use, combined with high machine traffic, has caused negative impacts in soil structure. Therefore, the management based on conservationist principles has proved to be efficient, improving chemical, physical, and biological soil properties [1-2]. Thereby, no-tillage system (NT) is considered a conservationist management, which characteristics are no soil plowing, ground cover with residue from the past crops, and crop rotation. From all the cultivated areas around the world, about 125 million hectares are maintained under NT, that is, only $9 \%$ of the agricultural land. However, such rate depends on each region of the world; Brazil, for example, is one of the main countries adopting such system, with around 37 million hectares [3] that comprise more than half of all areas cultivated with grain crops. Nevertheless, from NT advent, problems such as soil subsuperficial compaction has been reported mainly at 0.10-0.20 m depth [4-5].

Aiming at compaction minimization, which occurs because of soil mobilization reduction and inappropriate management systems, maize and forage grasses intercropping has been added to NT. Urochloa spp. have been used as soil conditioners because these plants may improve soil physical properties due to high root density and plant cover besides reducing weed emergence. Those species act both at the crop establishment stage and after harvest because of great biomass production, what results in a good soil cover [6].

The state of Paraná, Brazil, in addition to being pioneer in adopting NT in the country, is one of the greatest maize second season producers, where intercropping with forage grasses may be highlighted. Both Northern and Western regions concentrate their production in maize second season; its cultivation success depends on favorable climatic conditions as, along the autumn-winter period, crops are vulnerable to some climatic limitations, such as water availability, solar radiation, and temperature [7]. Therefore, in areas where the climate is warmer, maize and forage grasses intercropping has been an option that brings satisfactory results. Apart from avoiding soil exposure to erosion after harvesting up to the cultivation of summer crops, it is an alternative for animal pasture after maize harvest [2]. Intercropping also results in either maintenance or increase of crop yield [8], as one of its objectives is, in fact, harmonize plant cover straw, i.e., crop residue, without impairing maize yield [2]. Maize and forage grasses intercropping has become, then, a promising alternative, as forage grasses have, potentially, high volume of vigorous roots that are able to promote improvements in soil structure, such as increased water infiltration ratio, formation of stable aggregates and biopores, decreased bulk density, and minor soil penetration resistance [2-9].

Several soil physical properties have been used to evaluate effects of maize and forage grasses intercropping due to the great importance of soil physical quality to promote appropriate conditions for growth and development of the root system. Soil resistance to penetration and water availability, porosity and bulk density, aggregate stability, tensile strength, and least limiting water range are considered the most used indicators of the soil physical quality [10]. However, these are laboratory methods, so, despite of their reliability, they often are time consuming and costly. Therefore, field methods, such as the visual evaluation of soil structure, have been gaining prominence because of low costs and potentially immediate achievement of results [11]. In this sense, a method of visual evaluation that has been much used in Brazil is the visual evaluation of soil structure (VESS) proposed by [12] and refined by [13]. This method allows simple and agile distinction of layers that presents structural differences. Also, it has been a great alternative for researchers and farmers, as it enables the analysis of soil layers via the verification of soil attributes such as aggregate stability, size, and porosity, besides root system behavior, among other characteristics. Many studies have used such method to distinguish management systems of both long term [14-16] and short term [17]. Munkholm and coauthors [18] found lower visual scores for a crop rotation system with barley and oat than for maize monoculture and maize-soybean succession, showing the effect of forage grasses on soil structural quality. Silva and coauthors [19] observed lower visual scores at the interrow cultivated with Urochloa sp. when compared with the non-cultivated interrow. The authors also noted that the planting effect was higher in the superficial layer, with lower visual scores than those found for the subsuperficial layer.

Although further studies were not found on visual structure evaluation of soils cultivated with maize and forage grasses intercropping, several ones used quantitative indicators to report the potential of forage grasses to improve soil physical quality [20,21].

The research hypothesis is that maize and forage grasses intercropping improves soil structural quality. Therefore, the objective was to perform the visual evaluation of soil structure in maize and forage grasses intercropping under no-tillage. 


\section{MATERIAL AND METHODS}

The experiment was carried out in Santo Antonio Farm, located in Borrazópolis county, Paraná State, Brazil ( $23^{\circ} 52^{\prime} \mathrm{S}$ and $51^{\circ} 32^{\prime} \mathrm{W}$, at $447 \mathrm{~m}$ mean altitude). Mean rainfall and annual temperature in the region are $1,556 \mathrm{~mm}$ and $19.4^{\circ} \mathrm{C}$, respectively. According to the Köppen classification, the local climate is humid subtropical (Cfa), and soil is classified as clayey Oxisol [22]. The chemical and granulometric analysis indicated $7.95 \mathrm{mg} \mathrm{dm}^{-3} \mathrm{P} ; 16.77 \mathrm{~g} \mathrm{dm}^{-3}$ organic carbon; $0.05 \mathrm{cmol}_{\mathrm{c}} \mathrm{dm}^{-3} \mathrm{Al} ; 4.62 \mathrm{cmol}_{\mathrm{c}} \mathrm{dm}^{-3} \mathrm{Ca} ; 0.93 \mathrm{cmol}_{\mathrm{c}}$ $\mathrm{dm}^{-3} \mathrm{Mg} ; 175 \mathrm{~g} \mathrm{Kg}^{-1}$ sand; $685 \mathrm{~g} \mathrm{Kg}^{-1}$ clay; and $140 \mathrm{~g} \mathrm{Kg}^{-1}$ silt at 0.00-0.20 m depth. The area where the experiment was implemented has been cultivated under no-tillage since 1997 with, mainly, maize (Zea mays), soybean (Glycine max), and wheat (Triticum spp.).

The experiment comprised five treatments: maize + Urochloa brizantha cv. Marandu (T1), maize + Urochloa brizantha cv. Piatã (T2), maize + Urochloa brizantha cv. Xaraés (T3), maize + Urochloa ruziziensis (T4), and non-intercropping maize (T5) (Fig.1). Each experimental plot had $95 \mathrm{~m}$ length and $9 \mathrm{~m}$ width. Seeds of the forage grasses were sown in $5^{\text {th }}$ April 2018 using a 19-row seeder (Semeato TD $300^{\circledR}$ ) of 30 seeds m${ }^{2}$ capacity, followed by maize (AS 1777 VT PRO3 ${ }^{\circledR}$ hybrid, Agroeste ${ }^{\circledR}$ ) sowing using an articulated 10-row seeder (Terraçu's ${ }^{\circledR}$, Planti Center ${ }^{\circledR}$ ) with a $50 \mathrm{~cm}$ row spacing.

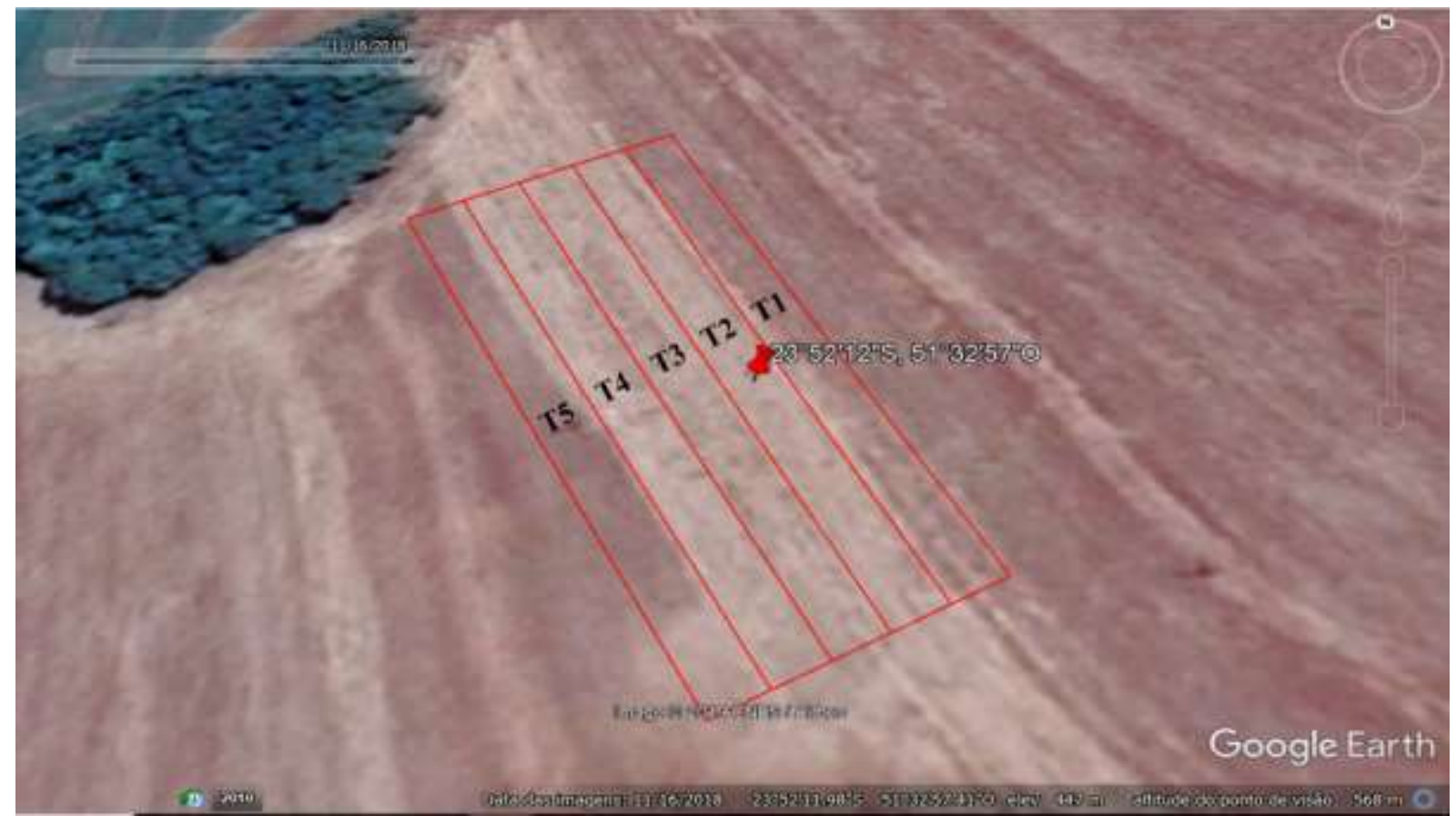

Figure 1. Aerial view of the experimental area with the treatments T1 (maize + Urochloa brizantha cv. Marandu), T2 (maize + Urochloa brizantha cv. Piatã), T3 (maize + Urochloa brizantha cv. Xaraés), T4 (maize + Urochloa ruziziensis), and T5 (non-intercropping maize). Source: Google Earth.

Sampling was carried out in December, $30^{\text {th }} 2018$, when five random locations for sample collection were selected from each treatment area. At each location in the interrow with forage grasses, a small trench was performed with the help of a straight shovel for the extraction of undisturbed samples of $10 \mathrm{~cm}$ width, $20 \mathrm{~cm}$ length, and $25 \mathrm{~cm}$ thickness. These samples were carefully placed on a tray and manually broken, however, before breaking them up into aggregates, it was observed whether the structure was either uniform or had different layers. Sample length and layers, when necessary, were measured with the help of a ruler. Then, considering the natural soil fracture lines of aggregates, samples were manipulated so that both visual and tactile analysis were performed, noting root and pore presence, and aggregate shape and resistance that, all together, were used for score attribution. Using a soil evaluation chart [13], a visual score was attributed (Sq) to each sample according to its structure. Following the step-by-step described in the chart, and visually analyzing the sample structure, the scores were balanced. Scores described in the chart range from 1 to 5 , so $\mathrm{Sq}=1$ to $\mathrm{Sq}=3$ are acceptable soils, and $\mathrm{Sq}=4$ and $\mathrm{Sq}=5$ indicate soils with structure compaction requiring management changes.

The final visual score for each sample was calculated according to the Equation 1:

$$
\mathrm{Sq} \text { tinal }=\left[\left(\mathrm{Sq}_{\text {sup }} \times \mathrm{D}_{\text {sup }}\right) / \mathrm{D}_{\text {total }}\right]+\left[\left(\mathrm{Sq}_{\text {sub }} \times \mathrm{D}_{\text {sub }}\right) / \mathrm{D}_{\text {total }}\right)
$$


Where:

$\mathrm{Sq}_{\text {final }}$ - final visual score; $\mathrm{Sq}_{\text {sup }}$ - visual score for the superficial layer; $\mathrm{Sq}_{\text {sub }}$ - visual score for the subsuperficial layer; $D_{\text {sup }}-$ depth of the superficial layer; $D_{\text {sub }}-$ depth of the subsuperficial layer; $D_{\text {total }}-$ total depth of the sample.

The mean confidence interval was considered a statistical criterion to differentiate and compare intercropping effects in the visual analysis of soil structure. Significant differences among intercropping systems were considered when there was no overlapping between upper and lower limits. The confidence interval establishes values where mean values of the data set are located, so it is an efficient and reliable method for the interpretation of significant differences [23].

\section{RESULTS AND DISCUSSION}

The standard deviation for all variables and treatments ranged from 0.06 to 0.50 (Table 1 ). These low values indicate that the visual scores presented minor dispersion around the mean. Considering maximum and minimum values, it is observed that there was no high variation among visual scores, what demonstrates that the samples used for visual evaluation presented low variability.

Table 1. Descriptive statistics for the variables final visual score (Sq), visual score for the superficial layer (Sqsup), and visual score for the subsuperficial layer ( $\mathrm{Sq}$ sub).

\begin{tabular}{|c|c|c|c|c|c|c|c|}
\hline Treatment $^{1}$ & Variable & Mean & Maximum & Minimum & $\mathrm{SD}^{2}$ & Variance & $\mathrm{CV}^{3}(\%)$ \\
\hline & Sq & 3.2 & 3.5 & 3.0 & 0.50 & 0.25 & 15.44 \\
\hline \multirow[t]{3}{*}{ T1 } & $\mathrm{Sq}_{\text {sup }}$ & 1.3 & 1.4 & 1.1 & 0.24 & 0.06 & 19.17 \\
\hline & $\mathrm{Sq}_{\text {sub }}$ & 2.0 & 2.2 & 1.8 & 0.38 & 0.14 & 19.27 \\
\hline & $\mathrm{Sq}$ & 2.7 & 2.8 & 2.6 & 0.12 & 0.01 & 4.41 \\
\hline \multirow[t]{3}{*}{ T2 } & $\mathrm{Sq}_{\text {sup }}$ & 0.8 & 0.9 & 0.7 & 0.21 & 0.04 & 25.47 \\
\hline & $S q_{\text {sub }}$ & 1.9 & 2.0 & 1.7 & 0.24 & 0.06 & 12.75 \\
\hline & $\mathrm{Sq}$ & 2.5 & 2.7 & 2.3 & 0.36 & 0.13 & 14.43 \\
\hline \multirow[t]{3}{*}{ T3 } & $S q_{\text {sup }}$ & 1.0 & 1.1 & 1.0 & 0.14 & 0.02 & 13.98 \\
\hline & $S q_{\text {sub }}$ & 1.5 & 1.7 & 1.3 & 0.38 & 0.14 & 25.44 \\
\hline & $\mathrm{Sq}$ & 3.0 & 3.1 & 2.8 & 0.29 & 0.09 & 10.13 \\
\hline \multirow[t]{3}{*}{ T4 } & $\mathrm{Sq}_{\text {sup }}$ & 1.2 & 1.3 & 1.2 & 0.06 & 0.004 & 4.88 \\
\hline & $S q_{\text {sub }}$ & 1.7 & 1.9 & 1.6 & 0.30 & 0.09 & 17.49 \\
\hline & $\mathrm{Sq}$ & 3.2 & 3.3 & 3.2 & 0.16 & 0.02 & 4.93 \\
\hline \multirow[t]{2}{*}{ T5 } & $S q_{\text {sup }}$ & 1.3 & 1.4 & 1.2 & 0.14 & 0.02 & 11.07 \\
\hline & $S q_{\text {sub }}$ & 1.9 & 2.0 & 1.9 & 0.13 & 0.02 & 6.62 \\
\hline
\end{tabular}

1T1: maize + Urochloa brizantha cv. Marandu; T2: maize + Urochloa brizantha cv. Piatã; T3: maize + Urochloa brizantha cv. Xaraés; T4: maize + Urochloa ruziziensis; and T5: non-intercropping maize. ${ }^{2}$ Standard deviation. ${ }^{3}$ Coefficient of variation.

The score variability may be analyzed from the coefficient of variation (CV) based on the classification proposed by Warrick and coauthors [24]: CV < 12\% (low variability), $12 \geq \mathrm{CV}<52 \%$ (medium variability), and $\mathrm{CV} \geq 52 \%$ (high variability). Therefore, Sq of T2, T4, and T5 presented low variability while T1 and T3 showed medium variability. For $\mathrm{Sq}_{\text {sup }}, \mathrm{T} 4$ and $\mathrm{T} 5$ had low variability and $\mathrm{T} 1, \mathrm{~T} 2$, and $\mathrm{T} 3$, medium variability. The $\mathrm{Sq}_{\text {sub }}$ showed low variability only for T5 while the other treatments presented medium variability.

Visual scores were significantly different among treatments (Figure 2), so T2 and T3 were different from the others with a mean visual score of 2.7 and 2.5, respectively. Treatments T1, T4, and T5 had the highest scores. Regarding the soil structural quality, T2, T3, and T4 did not present a structure considered compacted, with visual score lower or equal to 3 (Figure 2). In the chart proposed by Ball and coauthors [12], the lowest value corresponds to the best structural quality, while the highest value to the worst quality. Treatments T2 and T3 presented a visual score of excellent structural quality, as soil was structured and composed of roots and biopores. Means of T1 and T5 visual scores were obtained because, during 
evaluation, soil structure showed evidence of compaction and an impaired structural quality, which aggregates had few pores and roots, besides angular shape and greater resistance to fracturing. In this sense, one of the reasons for T1 high visual score was more root development at the inferior layer of Urochloa brizantha cv. Marandu when compared with the other grasses (Figures $3 a$ and $3 b$ ). Such forage grass species produced minor soil cover that, in addition to an inferior root development observed in the visual evaluation, promoted low influence in soil structure and was equal to non-intercropping maize.

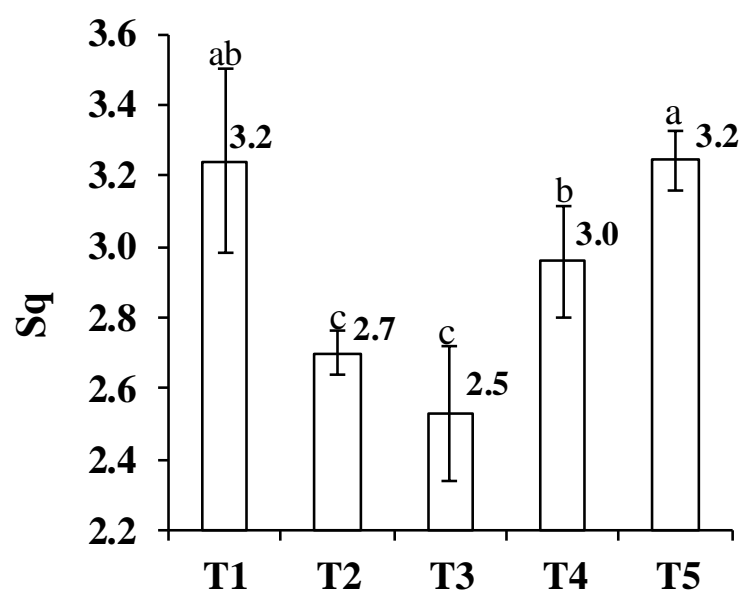

Figure 2. Mean final visual score $(\mathrm{Sq})$ for treatments $\mathrm{T} 1$ (maize + Urochloa brizantha cv. Marandu), T2 (maize + Urochloa brizantha cv. Piatã), T3 (maize + Urochloa brizantha cv. Xaraés), T4 (maize + Urochloa ruziziensis), and T5 (non-intercropping maize). Means followed by the same letter do not differ statistically from each other according to the confidence interval.

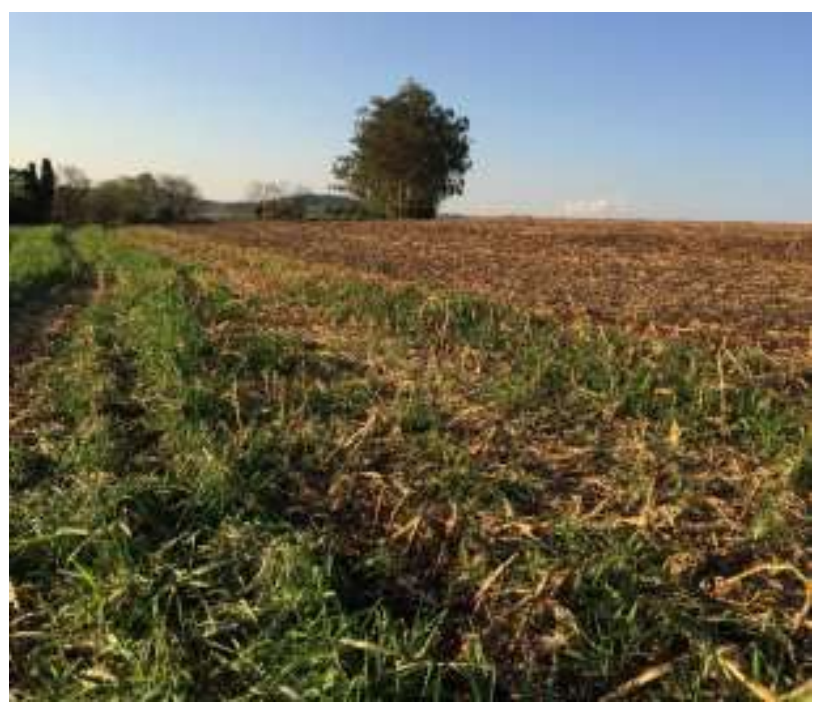

a)

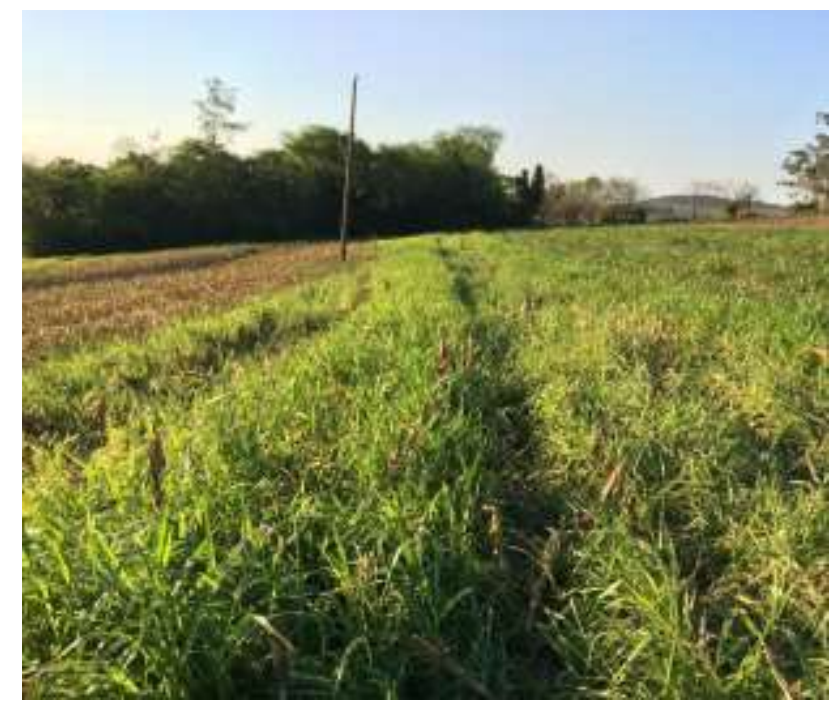

b)

Figure 3. Treatments at the experimental plot after maize harvest: a) maize + Urochloa brizantha cv. Marandu (T1) and b) maize + Urochloa ruziziensis (T4).

At the collecting locations, two layers were observed at the soil samples from all treatments, with structural differences like those found by Mazon and coauthors [25] in clayey Oxisol areas of integrated croplivestock and hay-crops. Therefore, when treatments are compared for each soil layer (Figures 4a and 4b), it is possible to observe that scores for the superficial layer are low for all treatments. For the superficial layer, T2 presented a score of 0.8 , the lowest among treatments, and was statistically different from the others; T3 had a mean score of 1.0 and was also different from the others. However, for the subsuperficial layer, the scores obtained were higher than those found for the superficial layer: T3 had a mean score $13 \%$ lower than T4, 26\% lower than T2 and T5, and 33\% lower than T1. However, T1, T2, T4, and T5 were statistically equal. When layers were compared using the visual evaluation, it was possible to note that the superficial layer presents better soil structure, while the highest visual scores in the subsuperficial layer indicate inferior structure quality. In this sense, maize and forage grasses intercropping was more effective to improve the 
soil structural quality at the upper layer. These results corroborate those found by Giarola and coauthors [26], who verified a lower visual score at the upper layer of a clayey soil.

The final visual score $(\mathrm{Sq})$ for T5 and T1 was 3.2, a value close to what was found by Giarola and coauthors [26] for an Oxisol area cultivated under no-tillage, which was a mean of 3.0. In comparison with non-intercropping maize (Figure 5a), T3 was the most highlighted treatment (Figure 5b) as it promoted good soil structural quality, with great number of roots and porous aggregates. Visual scores for T3, for both superficial and subsuperficial layers (1.0 and 1.5, respectively), were very close, what proves that maize and forage grasses intercropping effect in this treatment was beyond the superficial layer. These results also showed that the implementation of maize and forage grasses intercropping under no-tillage improves soil structural quality, acting towards a more porous soil with better aggregation.
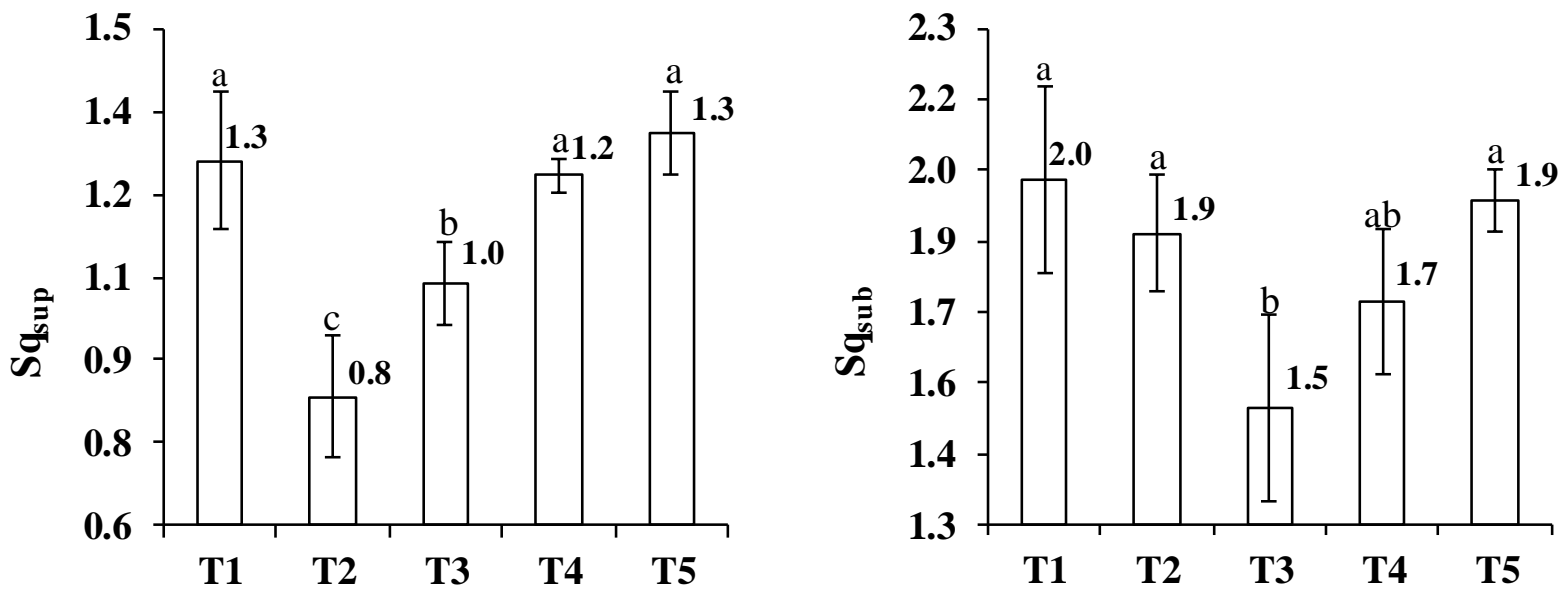

Figure 4. Mean visual score for the superficial layer $\left(\mathrm{Sq}_{\text {sup }}\right)$ and subsuperficial layer $\left(\mathrm{Sq}_{\text {sub }}\right)$ for treatments $\mathrm{T} 1$ (maize + Urochloa brizantha cv. Marandu), T2 (maize + Urochloa brizantha cv. Piatã), T3 (maize + Urochloa brizantha cv. Xaraés), T4 (maize + Urochloa ruziziensis), and T5 (non-intercropping maize). Means followed by the same letter do not differ statistically from each other according to the confidence interval.

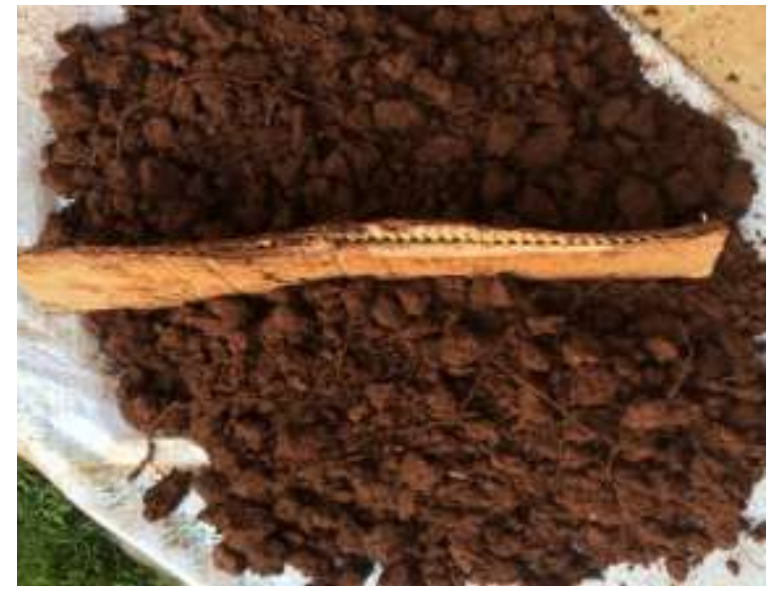

a)

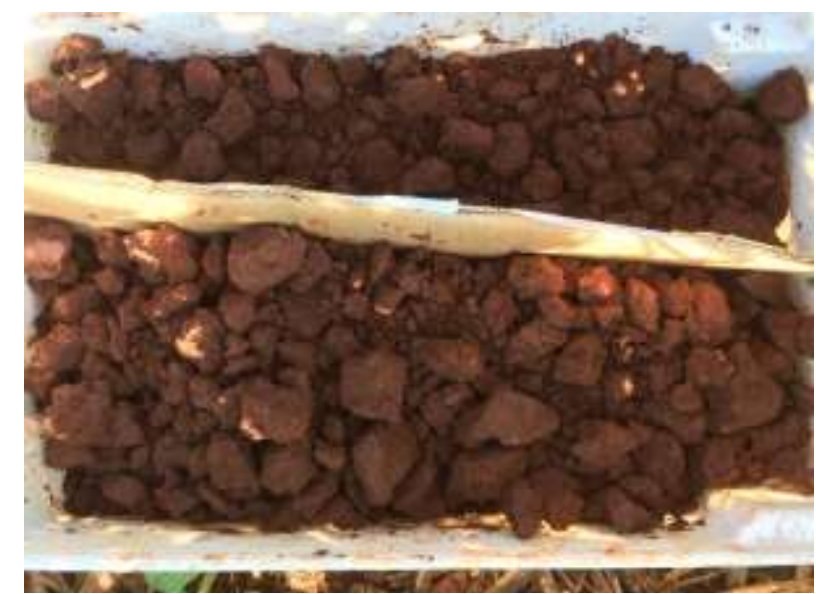

b)

Figure 5. Soil layers obtained from the visual evaluation of soil structure (VESS) for a) maize + Urochloa brizantha cv. Xaraés (T3) and b) non-intercropping maize (T5).

Different results were reported by Giarola and coauthors [27] for an Oxisol when using VESS to analyze soils from areas of forest, integrated crop-livestock, and no-tillage. The forest soil had a mean score lower than those found in this study $(\mathrm{Sq}=1.70)$. According to the authors, the low mean score found in those conditions is due to lack of soil plowing, what maintains the structure homogeneity along the soil profile. Although T2 and T3 values are superior to those found by Giarola and coauthors [27], these results denoted that maize and forage grasses intercropping may also promote layer homogeneity along time due to root power to decompaction soil. Therefore, when T2 and T3 are compared with T5, it is concluded that, when no-tillage system is not managed appropriately, it may lead to soil structural degradation. 
Similar results to T1, T3, and T5 were also reported by Tuchtenhagen and coauthors [17], who analyzed VESS in soils cultivated under native pasture, integrated crop-livestock, no-tillage, and conventional agriculture. Scores attained for no-tillage (2.5) was equal to T3 (2.5), and those found for conventional agriculture (3.2) was the same shown by $\mathrm{T} 1$ and T5. Those authors report that a score equal to 3.0 indicates the possibility of most aggregates to be ruptured by hand, besides having porous aggregates ranging from 2 to $100 \mathrm{~mm}$ and some non-porous angular clods. This is a similar condition to what was found for T1 and T5. According to those authors, scores over 3.0 indicate the need for short-term management changes.

In an experiment with a clayey Oxisol [25], visual scores superior to those found in this study were obtained. For the superficial layer, mean score was 3.105 for hay + crops and 3.975 for integrated croplivestock; for the subsuperficial layer, it was 3.92 and 3.23 for hay + crops and integrated crop-livestock, respectively.

Comparing all treatments, it is observed that scores obtained from the visual evaluation of soil structure indicated that maize and forage grasses intercropping improved the soil physical structure mainly in the superficial layer. This increases the soil volume with appropriate structural quality to be explored by the roots of the subsequent crops. Therefore, porous spaces may be better used by promoting more soil-root contact [28]. This behavior was visually noted for all treatments with forage grasses, which presented aggregates that were more porous and stable, less angular, and with more roots; the exception was T1 where the forage grasses did not develop well. In a short-time evaluation, the maize and forage grasses intercropping indicated, using VESS, that forage grass plants promoted beneficial changes at the crop interrow. This is especially important because the interrow is the most trafficked area because of management operations along crop cycles.

Funding: This research received no external funding.

Acknowledgments: Thanks to farmer Daniel Garcia Paschoal for allowing the use of the experimental area.

Conflicts of Interest: The authors declare no conflict of interest.

\section{REFERENCES}

1. Santos JB. Manejo do Solo. In: Bertol OJ, Colozzi Filho A, Barbosa GMC, Santos JB, Guimarães MF. Manual de Manejo e Conservação do Solo e da Água para o Estado do Paraná. 1. ed. Curitiba: Núcleo Estadual Paraná da Sociedade Brasileira de Ciência do Solo - NEPAR-SBCS; 2019. p. 104.

2. Conceição PC. Práticas Conservacionistas. In: Bertol OJ, Colozzi Filho A, Barbosa GMC, Santos JB, Guimarães MF. Manual de Manejo e Conservação do Solo e da Água para o Estado do Paraná. 1. ed. Curitiba: Núcleo Estadual Paraná da Sociedade Brasileira de Ciência do Solo - NEPAR-SBCS; 2019. p. 112.

3. Blanco Canqui H, Ruis SJ. No-tillage and soil physical environment. Geoderma. 2018 Sept; v. 326, p. $164-200$.

4. Franchini JC, Costa JM, Debiasi H, Torres E. Importância da rotação de culturas para a produção agrícola sustentável no Paraná. Documentos 327. Embrapa Soja. Londrina, PR. Jun. 2011.

5. Bottega EL, Bottega SP, Silva SA, Queiroz DM, Souza CMA, Rafull LZL. Spatial variability of soil resistance to penetration in an Oxisol. Rev. Bras. Ciênc. Agra. 2011, v.6, n.2, p. 331-6.

6. Mendonca VZ, et al. Evaluation of soil physical properties in a forage corn intercropping in succession with soybean in the cerrado region. Rev. Bras. Ciênc. Solo. 2013, vol.37, n.1, pp.251-259.

7. Franco AAN, Marques OJ, Vidigal Filho OS. Sistemas de Produção do Milho Safrinha no Paraná. Em: EMBRAPA, UFGD. Milho Safrinha XII Seminário Nacional; 26 a 28 de novembro de 2013.

8. Santos GG, Silveira PM, Marchão RL, Becquer T, Balbino LC. Soil macrofauna communities and cover crops in a Cerrado Oxisol under no tillage. Pesquisa Agropecuária Brasileira. 2008; v.43, p.115-22.

9. Balbinot Junior AA. Winter soil use: soil properties, weed infestation and maize Performance. Tese (doutorado) Universidade Federal do Paraná, Curso de Pós-graduação em Agronomia. 2007.

10. Fidalski J, Tormena CA. Pedotransfer functions for the soil water retention and soil resistance to penetration under groundcover management systems in citrus. Ci. Rural. 2007; v. 37, p. 1316-22.

11. Cui J, Askari MS, Holden NM. Visual Evaluation of Soil Structure Under Grassland management. Soil Use and Management. 2014; v. 30, n. 1, p. 129-38.

12. Ball BC, Batey T, Munkholm LJ. Field assessment of soil structural quality - a development of the Peerlkamp test. Soil Use and Management. 2007; v. 23, n. 4, p. 329-37.

13. Guimarães RML, Ball BC, Tormena CA. Improvements in the visual evaluation of soil structure. Soil Use and Management. 2011; v. 27, n. 3, p. 395-403.

14. Askari MS, Cui J, Holden NM. The visual evaluation of soil structure under arable management. Soil Tillage Res. 2013; v. 134, p. 1-10. 
15. Cherubin MR, Franco ALC, Guimarães RML, Tormena CA, Cerri CEP, Karlen DL, Cerri CC. Soil v. 380 , p. 133 Assessing soil structural quality under Brazilian sugarcane expansion areas using Visual Evaluation of Soil Structure (VESS). Soil Tillage Res. 2017; v. 173, p. 64-74.

16. Tormena CA, Karlen DL, Logsdon S, Cherubin MR. Visual Soil Structure Effects of Tillage and Corn Stover Harvest in lowa. Soil Sci. Soc. Am. J. 2016; v. 80, p. 720-6.

17. Tuchtenhagen IK, Lima CLR, Bamberg AL, Guimarães RML, Pulido-Moncada M. Visual evaluation of the soil structure under different management systems in lowlands in Southern Brazil. Rev. Bras. Ciênc. Solo. 2018; v. 42, p. 1 - 13.

18. Munkholm LJ, Heck RJ, Deen B. Long-term rotation and tillage effects on soil structure and crop yield. Soil Tillage Res. 2013; v. 127, p. 85-91.

19. Silva AP, Ball BC, Tormena CA, Giarola NFB, Guimarães RML. Soil structure and greenhouse gas production differences between row and interrow positions under no-tillage. Sci. Agric. 2014; v. 71, p. 157-62.

20. Calonego J C, Borghi E, Crusciol C A C. Intervalo Hídrico Ótimo e compactação do solo com cultivo consorciado de milho e braquiária. Rev. Bras. Ciênc. Solo, v. 35; 2011; p. 2183-90.

21. Cagna CP, Calábria ZKP, Guedes Filho O, Pacheco LP, Silva TJA. Structural Properties of Soil in Maize and Forage Grass Intercropping under No-tillage in the Brazilian Cerrado. Engenharia Agrícola. 2019; v. 39, p. 512-7.

22. Santos HG, Jacomine PKT, Cunha dos Anjos LH, Oliveira VA, Lumbreras JF, Coelho MR, et al. Sistema Brasileiro de Classificação de Solos. 3 ed. Brasília: Embrapa; 2013.

23. Payton ME, Miller AE, Raun WR. Testing statistical hypothesis using standard error bars and confidence intervals. Commun. Soil Sci. Plant. Anal. 2000; v. 31, p. 547-51.

24. Warrick AW, Nielsen DR. Spatial variability of soil physical properties in the field. In: HILLEL, D., ed. Applications of soil physics. New York, Academic Press, 1980. p. 350.

25. Mazon S, Guimarães RML, Zanchettin S, Hoffmann LP, Perufo AK, Acorsi VA. Potencial da avaliação visual da estrutura do solo (VESS) sob diferentes usos e manejos. XXXV Congresso Brasileiro de Ciência do Solo; 02 a 07 de agosto de 2015; Natal, RN.

26. Giarola NFB, Silva AP, Tormena CA, Ball B, Rosa JA. Visual soil structure quality assessment on Oxisols under notillage system. Scientia Agricola. 2010; v.67, p.479 - 82.

27. Giarola NFB, Tormena CA, Silva AP, Ball B. Visual assessment soil quality structure methodology applied to Oxisol under different soil use and management. Ciênc. Rural. 2009; v.31, p. 39.

28. Bodner G, Leitner D, Kaul HP. Coarse and fine root plants affect pore size distributions differently. Plant and Soil. 2014.

2020 by the authors. Submitted for possible open access publication under the terms and conditions of the Creative Commons Attribution (CC BY NC) license (https://creativecommons.org/licenses/by-nc/4.0/). 